University of Chicago Law School

Chicago Unbound

Journal Articles

Faculty Scholarship

1983

\title{
Common Law, Labor Law, and Reality: A Rejoinder to Professors Getman and Kohler
}

Richard A. Epstein

Follow this and additional works at: https://chicagounbound.uchicago.edu/journal_articles

Part of the Law Commons

\section{Recommended Citation}

Richard A. Epstein, "Common Law, Labor Law, and Reality: A Rejoinder to Professors Getman and Kohler," 92 Yale Law Journal 1435 (1983).

This Article is brought to you for free and open access by the Faculty Scholarship at Chicago Unbound. It has been accepted for inclusion in Journal Articles by an authorized administrator of Chicago Unbound. For more information, please contact unbound@law.uchicago.edu. 


\title{
Common Law, Labor Law, and Reality: A Rejoinder to Professors Getman and Kohler
}

\author{
Richard A. Epstein†
}

Some readers of my Article may take a certain comfort in the response of Professors Getman and Kohler, ${ }^{1}$ and its reaffirmation of the New Deal verities I have criticized. If my assumptions offend "reality," then it is unnecessary to confront their implications. Reexamination of first principles is always hard, and often unpleasant, especially if it entails a change in orientation or commitment. Better it is, if we can continue untroubled on our old course.

Yet a closer look at Getman and Kohler's own work should be sufficient to dissipate any complacent support for the status quo. It should be apparent that Getman and Kohler present no hint of any theory, normative or positive, relevant to labor relations, or indeed to any other legal area. Nonetheless it takes a theory to beat a theory, so it is wholly insufficient for them to belittle the use of common law arguments without some explanation as to why these arguments are wrong or why they should be replaced.

Nor is the common law an easy target. Common law rules rest on more than the authority of the judges. Their intellectual roots derive from the libertarian and utilitarian tradition of Locke, Hume, Bentham, and Mill. The rules on the acquisition and protection of property, the keeping of promises, the importance of telling the truth and of keeping your hands to yourself are not remote or archaic conceptions. They are the stuff of all our everyday interactions. The simplicity of these common law structures allows them to cover a wide range of legal and social issues that are otherwise treated on a wholly ad hoc basis. Common law principles foster the operation of firms, the growth of trade and commerce, the law of the family and of the person. Why then is it self-evidently false and unreal to rely upon them, as the deposit of our shared moral life, when analyzing the field of labor relations, with its own heavily contractual component?

What do Getman and Kohler do to keep their own perspective alive?

$\dagger$ James Parker Hall Professor of Law, University of Chicago. My thanks go to Douglas Baird for his comments on an earlier draft of this paper.

1. Getman \& Kohler, The Common Law, Labor Law, and Reality: A Response to Professor Epstein, 92 YALE L.J. 1415 (1983). 
The written evidence shows that they are ill-equipped to enter into any serious intellectual debate that does not accept the soundness of their own political assumptions. At some points their Comment rests upon simple upper-class bias. They write, "Mass production techniques increasingly made skills obsolescent and workers fungible." The proposition is obviously false to anyone who has ever watched two carpenters work side by side. More importantly it is false even in mass production industries. Why else is there the great concern for quality control in the automobile industry, expressed both by Detroit and its critics?

At other points, Getman and Kohler take refuge in the opinion of others. They rely on the rhetoric of prominent labor leaders, such as Samuel Gompers or John Mitchell, ${ }^{3}$ to explain the goals and aspirations of unions. But at no point do they explain why partisan statements give us an accurate account of union behavior. They recount the reports of political commissions, ${ }^{4}$ the speeches of bar association presidents and Senators, ${ }^{5}$ or work done by economists and sociologists, such as Commons, Witte and Weber, fifty years ago. ${ }^{6}$ Yet they show no awareness of any of the economic work done in the past generation on agency costs, bargaining theory, economic rents, collective action, imperfect information, public choice or monopoly power. At critical junctures they speak about "values" and "American ideology." Nonetheless, they fail to say anything concrete about my specific substantive criticisms of the National Labor Relations Act or of my detailed defense of common law ideas, including the yellow dog contract. Their political commitment is everywhere. Their intellectual commitment, invisible.

My criticism goes not only to their general orientation. It also extends to some of the specific points that they make in their Comment. It is sufficient to identify several here.

First, Getman and Kohler are wrong to assert that the present system of labor relations depends upon private bargains and not upon government intervention. It is clearly an amalgam of both. To be sure, the government does not negotiate the terms, but it does set the basic framework in which those terms are negotiated. It holds union elections; it polices unfair labor practices; it determines bargaining units; it regulates secondary boycotts. Getman and Kohler could scarcely argue that the terms of labor-management negotiations are unaffected by government intervention, or else they would not want to defend the present order. At best they

2. Id. at 1418.

3. Id. at 1422 .

4. Id. at 1425 .

5. Id. at 1428 .

6. Id. at 1427-30.

7. Id. at 1421. 
have shown that government intervention could be more intrusive and ham-handed than it is. We should be grateful for whatever rationality our system does possess, for the British experience shows us how easy it is to do worse, far worse, than we have done. It hardly follows that the current position represents the social optimum.

Second, Getman and Kohler are wrong to assert that the proposition that private contracts work to the mutual benefit of both parties is simply a matter of ipse dixit. ${ }^{8}$ The proposition follows from the general assumption about economic self-interest in the market place, at least if one assumes that workers possess any intelligence and competence. They might as well have said that they have refuted the Coase theorem, which rests upon just this assumption. ${ }^{\circ}$ Nor does the proposition here depend solely upon theoretical arguments. With the yellow dog contract, for example, it is easy to identify the sources of gain, not only to the employer, but also to the workers who sign them: wages are as high as they are with the union, employment is steadier, and union obligations need not be met.

Getman and Kohler think, however, that they can make their case by being wholly negative. Yet it is fair to ask in response: How do they think the world operates if this proposition is as a general matter false? Their position is deeply troubling as a moral matter. If contracts do not work to the benefit of the parties to them, what sense do they make of marriage, partnership, friendship, or business relationships? What about academic institutions? Why do they allow people to vote or to participate in public life? To deny the assumption about mutual benefit is literally to call into question the rationality of human behavior. It is to think that the world is truly a chaotic and a disordered place. It is to credit persons with so little knowledge of their own preferences and desires that one wonders why we should bother to respect any individual rights at all. It is, in the end, to denigrate the importance and integrity of the individual.

Their position is also deeply troubling as a descriptive matter. The key difficulty is that they have no discernible behavioral assumptions of their own. Do they want us to assume that workers, especially those who are faced with general privation, systematically enter into contracts that make them worse off? If not, then how do workers behave and why? Getman and Kohler's unsystematic and anti-intellectual approach ends all serious discussion about all serious issues. It leads to no empirically verifiable results and has no descriptive power.

The proof of the pudding is in the eating. Getman and Kohler do not stick to their original position when they wish to make their own affirma-

8. Id. at 1429 n.63. I discuss the point in detail, Epstein, A Common Law for Labor Relations: $A$ Critique of the New Deal Labor Legislation, 92 YALE L.J. 1357 (1983).

9. See Coase, The Problem of Social Cost, 3 J. L. \& EcoN. 1 (1960). 
tive case. They implicitly resort to the assumption that contracts work to the mutual benefit of the parties in explaining the behavior of workers, employers and unions under the current law. Thus "[a]s long as employees have the right to unionize, non-union employers are motivated to pay union scale or above, and employees are in a position to monitor the indirect promises which are a regular feature of union organizing campaigns."10 But that monitoring succeeds only if workers can compare alternatives in a rational manner, which Getman's own work suggests that they are able to do. ${ }^{11}$ Indeed, mutual self-interest lies at the heart of current law, for why allow collective bargaining agreements at all if workers do not know their own self-interest when they vote on contract ratification? If anything, the current institutional structure makes workers' choices more difficult than they were at common law, given the present need for collective choices to resolve intra-union conflicts. Yet Getman and Kohler never explain why workers, who can maneuver in the current environment, lack similar competence to make intelligent choices under a simpler common law regime. All they show us is what everyone knows, that some union workers at least are better off under the current law than under the common law. But they have no social criterion, be it the minimization of force and fraud or the maximization of individual utility, to explain why their position is a social good.

Third, Getman and Kohler rebuke me for not offering empirical evidence for my position. But that in no way detracts from the importance of developing a theory that helps make sense of the empirical data that is collected. Note too that Getman and Kohler offer no new empirical evidence of their own, and because of their total indifference to theory, they cannot even begin to interpret the empirical studies they do mention. ${ }^{12}$

10. Getman \& Kohler, supra note 1, at 1423. Note that the argument is good even without collective bargaining, although the wage levels should be expected to change.

11. Getman, Goldberg, \& Herman, The National Labor Relations Board Voting Study: A Preliminary Report, 1 J. LEGAL STUD. 233 (1972).

12. See S. Slicter, J. HEALY, E. LiverNash, THE IMPaCT of COllective Bargaining ON MANAGEMENT (1960). The book is a huge study of labor relations whose method is well stated in the Author's Preface written by Healy and Livernash:

In undertaking this study our objective was to discover as much as we could about what has happened and is happening in a significant number of union-management situations. To accomplish this, we talked directly and informally with many management and union representatives to learn in some detail their labor relations experiences. Although we outline in a general way the topics we wished to investigate, ruling out any attempt to assess the broad economic impact of unions, we did not formulate any precise hypotheses for investigation. We followed Professor Slicter's characteristic approach of trying to acquire through extensive interviews a feeling for important developments in labor relations.

Id. at ix. The book is faithful to the method. It is a mine of information, but it lacks all theoretical coherence, and does not address the questions of institutional arrangement to which my paper is directed.

The second source cited is R. FREEMAN \& J. MEDOFF, WHAT Do UNIONS DO? (1984). The book had not been published when I wrote my article, but I did refer to their earlier study, Freeman \& 
Take for example their claim that union workers have been found, on average, to be as productive as non-union workers. ${ }^{13}$ Getman and Kohler treat the insight as though it carried the day on the soundness of the current labor laws. The inference is far too hasty, even if the data are correct. Note two theoretical complications.

There is first the question of holding inputs constant. The empirical work typically controls for a number of observable variables that have a connection to productivity: education, years of experience, age, marital status and the like. But the productivity equation is far more complex, and is influenced by variables that are far more difficult for an outsider to observe and quantify. Nonetheless, if unions promise a higher wage, one should expect a larger number of individuals to queue up for the available jobs. The employer (or union official) has every interest in getting the best workers for the stipulated wage, and he should be able to observe characteristics that an outside analyst might miss, be it in dress, attitude, speech or the like. He can be expected to pick superior workers from the queue, who will then demonstrate the greater productivity. It need not follow therefore that unions themselves increase the level of productivity of workers. They may simply be able to attract a superior class of workers to union jobs, workers who in more competitive markets would take positions elsewhere. The high level of union productivity might well mask a reduced overall level of social productivity as good workers seek union positions in order to share monopoly rents. In other words, unions tend to distort the relative price levels and so lead to a misallocation of resources. The private gains to union workers thus stem from redistribution and do not reflect any social increase in wealth.

A second factor also must be taken into account. Where labor markets are in equilibrium, one must expect that union workers will on average have higher productivity than nonunion workers to offset their higher wages. Otherwise union firms will be driven out of the market by cheaper competition. Nonetheless there is nothing in this observation that establishes that the current collective bargaining laws reach a social optimum. It is probable that certain firms have been unable to survive either the threat or the fact of unionization. The loss of these firms must be reflected in any total picture, but it will not be captured in any study that mistakenly confines its attention to the wage and productivity profiles of those firms able to survive unionization.

The same methodological mistake can bias the analysis of collective bargaining. Classical economic theory predicts that, after an initial shake-out,

Medoff, The Two Faces of Unionism, 57 PUB. INT. 69 (1979). For a discussion of some of their arguments, see infra p. 1440.

13. Getman \& Kohler, supra note 1, at 1432-33. 
the workers under collective bargaining will often show a high level of satisfaction. Yet again the survivorship issue must be confronted. The existing firms are those in which workers and unions are able to overcome their organization problems, largely because of a low variation in preferences among group members. The satisfaction of the winners, however, ignores those workers who were unable to obtain entry into the unionized firm, or those who left because they did not fit into its collective structure. Getman and Kohler never explain why the happiness of the winners, i.e. unionized workers, should be treated as a social justification if unionization is a negative-sum game for society at large. Why should unionized workers prosper at the expense of their less fortunate fellow workers? The consuming public? The employer who wishes not to contract with them? Getman and Kohler's praise of the current law does not follow from the empirical work on which they uncritically rely.

Getman and Kohler are similarly misguided on other empirical questions. They quote passages from Freeman and Medoff on the relationship between unions and wage inequality. ${ }^{14}$ They note that unions do increase the wage inequalities in some situations, but that this is acceptable because unions favor wage equalization within establishments, equal pay for equal work across establishments, and reductions in white- and bluecollar wage differentials generally. But what Getman and Kohler never do is explain to us why these interferences in markets are warranted. Where different levels of investment are necessary for different types of work, wage differentials are desirable, for otherwise there is an oversupply at one end of the market and an insufficient supply at the other. For its part, equal pay for equal work leaves all its basic terms undefined, and promises only the kind of administrative nightmare that hardly counts as a self-evident good. Again one needs a theory which explains why wage equality is a good or a bad thing. Getman and Kohler offer none.

Finally, Getman and Kohler misstate the nature of my proposals. A belief in contractual ordering does not require a commitment to any particular contractual form. I happen to be a defender of the contract at will, and oppose all efforts to make that contract illegal and against public policy. ${ }^{15}$ But I have no wish to ban collective agreements where they are entered into voluntarily. If unions do provide the net benefits that Freeman and Medoff insist they do, then some firms will court them even if mandatory collective bargaining becomes a thing of the past. But the issue that divides me from Getman and Kohler is the in-kind subsidy that is given union groups under the present labor law. They repeatedly speak of

14. Id. at 1432 n.77.

15. See Epstein, In Defense of the Contract At Will, 52 U. CHI. L. REV. (forthcoming) (1984). 
workers' rights of free association. ${ }^{16}$ Yet nowhere do they address the correlative duties. They do not explain why employers do not have rights of free association, or why these rights are denied to dissenting workers within the bargaining unit. Nor do they explain why it is in the social interest to subsidize one group of workers at the expense of employers and rival workers. Presumably the citizenry at large should receive some benefit in return for the costs it is made to bear by the barriers the legal system throws in the way of voluntary markets. Yet Getman and Kohler do not begin to explain why higher prices and reduced labor mobility work in the public interest. Instead they are content to trot out disconnected historical anecdotes in the mistaken belief that the intensity of their own convictions is a substitute for rational argument. Getman and Kohler seek to portray me as a defender of narrow class privilege, even though I am as opposed on principle to special protection for firms as I am to special protection for workers. Rather, it is they, and the New Deal legislation that they defend, that represent the triumph of the special interest over the public welfare.

16. Getman \& Kohler, supra note 1, at $\mathbf{1 4 3 0 .}$ 